\title{
Education in Northern Ireland since the Good Friday Agreement: Kabuki theatre meets danse macabre (Final)
}

\begin{abstract}
The Good Friday Agreement (1998) between the UK and Irish governments, and most of the political parties in Northern Ireland, heralded a significant step forward in securing peace and stability for this troubled region of the British Isles. From the new-found stability, the previous fits and starts of education reform were replaced by a determination for modernization and innovation, infused with a new energy and momentum. This sense of purpose embraced a complex weave of ideas and ideals; all designed variously to smooth, celebrate and harness community differences for the collective good. Much progress has been made in the intervening years since 1998, particularly in political structures and relationships. However, the euphoria of the new dawn of the Agreement had barely begun to shape the future before entrenched 'tribal' tensions reproduced the same political and legislative impasses of former years and visited their all-too-familiar blight on the economic, cultural and educational landscapes. This paper focuses on two signature dimensions of education that have been sustained by this partisanship: segregation by religion and segregation by academic selection.
\end{abstract}

\section{Introduction}

Northern Ireland society may be characterized as a spectrum of political aspirations bookended by violent extremists pursuing either continued union with Great Britain (loyalist paramilitaries) or reunification of Ireland (republican paramilitaries). The large majority in between may have unionist or nationalist sympathies but their overarching desire for a peaceful resolution of their differences was given voice with their $71 \%$ 'Yes' vote in the referendum on the Good Friday Agreement. Also known as the Belfast Agreement, it was signed by the British and Irish governments and most of the political parties in Northern Ireland on Good Friday, 10 April 1998 (NIO, 1998). Prior to this, there had been 26 years of direct rule in which the UK government-of-the-day appointed a secretary of state to run the country because, to put it bluntly, the local politicians could not be trusted to do it themselves. In 1972, direct rule by Westminster had finally brought the unionist-controlled Northern Ireland parliament to book for its 50 years of partiality and self-aggrandisement since the state was established in 1921. With a tenacious civil rights movement seeking equality of opportunity for the Catholic community, in employment, housing, education and a host of other social contexts, a London appointed secretary of state was viewed in many quarters as having the potential to be objective and fair, and most importantly a force for reform. Regrettably, the genie of vicious community and paramilitary violence had already been released from the bottle and for many years the London appointees, and their portfolio ministers and civil servants, were as much under siege as the communities they were serving.

The Good Friday Agreement returned a semblance of self-determination to these communities and was indisputably one of the most positive and momentous events in Northern Ireland's troubled history. It had a profound effect on how Northern Ireland politics work and the relative stability that Northern Ireland now enjoys, with its own devolved assembly established in December 1998, can be directly linked to the Agreement's founding principle of power sharing. Although one of the largest parties, the Democratic Unionist Party (DUP), had categorically rejected the Agreement (and arguably accounted for most of the $29 \%$ 'No' vote in the referendum), it breathed new life into Northern Ireland society. A generation was waking up to the novel prospect, for them, of selfgovernment in many key areas of devolved responsibility; and the wave of optimism that accompanied the Agreement gave a strong fillip to those who saw a need for reform in the education system. For too long a variety of problematic issues had had insufficient scrutiny in terms of their fit 
to a changing world. Some of these still obtain today, for example the statutory requirement for children as young as 4-years 2-months to enter formal schooling, but the focus of this paper will be on the two signature dimensions of the Northern Ireland education system that make it stand out as unusual in the UK and indeed in comparison to most modern developed societies. These are the segregation of schoolchildren on the basis of religion and segregated access to secondary-level education based on controversial assessments of children's ability to benefit from a grammar school education. The one is variously blamed for the lack of social cohesion that fuels inter-community strife whilst the other is similarly tarred with the brush of condemning thousands of young people each year to lowered aspirations and life-chances.

There are many commentators on the strengths and weaknesses of schooling in Northern Ireland; some of them explicitly political, leaning left or right. Informing the various debates down through the years are the reports of specially commissioned review bodies, research evidence from academics and educational organizations including charities, and the data captured and processed by statutory curriculum and governance bodies, including the school inspectorate. Inevitably, much of this evidence gives rise to demands for intervention and to proposals for system change, designed to correct the perceived imbalances and weaknesses. These in turn sponsor various attempts at change, for example in how the school system is organized or how teacher training is provided. However, experience has it that Newton's Third Law invariably holds: forces for change generate equally energetic counter forces seeking to maintain the status quo.

Given the complexity outlined above, there was a temptation in writing this paper to explore the layers of Bourdieusian 'doxa' and 'habitus', the entrenched beliefs and practices underlying the invariant positions and intransigence of many of the actors in the Northern Ireland political system. When powerful opposing groups seem deliberately to eschew the reflexivity that might modify their centuries-old dispositions, and instead attempt to browbeat or simply coerce the 'opposition' to their own unchanged way of thinking, the impact on social constructs such as education is massive. Innovation is smothered and 'moving with the times' is more a stuttering journey, stopped and interrogated at every decision point, than a seamless process informed by international norms and tailored for local needs. There is a sense in which academics have always viewed Northern Ireland education as a type of sociological experiment existing within, and sometimes attempting to change, a society of polar opposites and multiple antagonists. However, instead of trying to unravel the deepdown psyches or the fundamental belief systems that govern the main actors' contributions, this paper seeks to chart developments in relation to education segregated by religion and academic selection since the time of the Agreement. Any such overview, however, must be prefaced with the acknowledgement that the matters being considered go to the very heart of Northern Ireland's riven society and it is therefore important to offer a brief history for each dimension.

\section{Religious Segregation of Schools}

Schooling in Ireland was first formalized in 1812 with government grants for those proposing to create schools that 'banished even the suspicion of proselytism' (Stanley 1831, p vii). However, by 1831 the Chief Secretary for Ireland, E. G. Stanley, was noting in a letter to the Duke of Leinster that the existing scheme's intention of creating national schools, which taught the 'Holy Scriptures without Note or Comment ... must be particularly obnoxious to a church which denies, even to adults, the right of unaided private interpretation' (Stanley, 1831, p viii). Stanley's famous letter recognized the Catholic Church's by then long-established opposition to the basis on which schools were being founded and sought to 'unite in one system children of different creeds' (Stanley, 1831, $p$ $x)$. The intention was to create an integrated system in which government aid for schools would only be available if joint applications were made by representatives of both denominations. Over time, however, any semblance of integration was lost and most of these national schools took on the complexion and ethos of their majority community. 
Universal education, introduced in England by the Elementary Education Act (1870), proved particularly tricky in Ireland and was not enacted until 1892. The delay was primarily due to opposition from all of the churches to the basic premise of the 1870 Act, which compelled 'every parent and guardian of a child to have it taught, at least, the rudiments of education, and that without reference to any religious creed or persuasion'. How could this be done unless the schools were non-denominational? - a non-starter for the churches.

The Northern Ireland state came formally into being in 1921, under the Government of Ireland Act (1920) which partitioned Ireland into two territories: the unionist, Protestant-majority north and the nationalist, Catholic-majority south. Brewer and Higgins (1998) describe how Northern Ireland had been established amidst grievous and violent antagonism between the two states. As a consequence, it was formed on the basis of a deliberate anti-Catholic and anti-nationalist rationale to counter the perceived threat of encroachment from the neighbouring Irish Free State that had emerged from the civil war between nationalist factions; a state that just as forcefully espoused a Catholic and antiBritish nationhood. The effect in the north was to ensure that the processes of government were already deeply tinged with the divisions that would persist in the future. The Catholic Church hierarchy and nationalist politicians in the north felt very much under siege and actively promoted a boycott of the Northern Ireland government. The result was that the members of the new parliament at Stormont were almost exclusively from the unionist tradition. Sectarian sentiment in the parliament on all issues, including education and employment, was largely unrestrained in its early days as elected Catholic nationalist members stayed away from the proceedings. In sectarian terms it was not a forum for the fainthearted and even some 10 years into its life, when a nationalist politician challenged the perceived discrimination against Catholics in government appointments, James Craig, the then prime minister, asserted that seeking appointees with 'unimpeachable loyalty to the King and Constitution ... [was his] ... whole object in carrying on a Protestant Government for a Protestant People' (Craig, 1934 p.73).

However, not all thinking in the new parliament was entrenched in diehard positions and in the early days there was some cause for hope. For example, a vigorous attempt to introduce integrated education was made by the parliament's first Minister of Education, Lord Londonderry. He commissioned the Lynn Committee to bring forward proposals for the re-organization of Northern Ireland schools, which he then took forward in the Education (Northern Ireland) Act 1923. However, his final proposals, including his rejection of the Lynn Committee's recommendation to introduce common scripture study into all schools, were attacked by both denominations primarily because the new school system would be secular and would wrest control of the schools from the churches. One unionist MP detected Londonderry's fading resolve in the face of this church opposition and expressed his regret that he did not 'take courage into his hand and give us secular schools ... but not godless by any means' (McGuffin, 1923, p.139). Londonderry finally tried to get buy-in from the churches with an impassioned appeal for them not to be 'the stumbling block in the way of an ideal system owing to a determination to segregate their flocks from birth and create a division' (Londonderry, 1923, p.125). In retrospect, they were more than mere stumbling blocks and the opportunity to disband segregated schooling in the new Northern Ireland state was lost.

\section{School Structure Today}

In 1923, the Lynn Committee proposed three types of schools for Northern Ireland education: county schools controlled by the Ministry of Education; so-called ' 4 and 2' schools in which the management committees had two ministry nominees with four nominated by the relevant church (mostly aimed at Catholic schools); and independently managed voluntary schools mostly aimed at the existing grammar school bloc. The Protestant churches resisted at first and then transferred their schools to government control ('controlled' schools of today) in return for the financial stability on offer. However, such was the resistance of the Catholic Church to any encroachment on their control of 
schools that it was not until 1968 that a form of the ' 4 and 2' management model (Catholic 'maintained' schools of today) was finally agreed with them. To this day, 'voluntary' Catholic and Protestant grammar schools are independent of government control, albeit within the boundaries of financial dependency and curricular and related compliance.

$* * * * * * * * * * * * * *$ Table 1: Numbers of schools (2014/15 and 1998/99) and their enrolments (sources: DENI, 2015a and DENI, 2012) ABOUT HERE**************

Table 1 sets out the main types of primary and secondary-level schools that exist in Northern Ireland in 2014/15 (for expedience, the table does not list preparatory departments of grammar schools (14), nurseries (96), special schools (39), independent schools (14) and one hospital school). 'Controlled' schools are often described as non-denominational and the figures bear out their much greater diversity in comparison to Catholic 'maintained' schools, albeit still with $68.3 \%$ and $81.4 \%$ designated Protestant majorities in the primary and non-selective secondary schools respectively. The Total Enrolment column also includes pupils designated as 'Other Christian', 'Non-Christian' or 'No Religion/Not Recorded' in 2014/15 and of these the very large majority (80.0\%) attend controlled schools, $8.4 \%$ attend Catholic schools and $10.7 \%$ attend grant maintained integrated schools. Designated Catholic pupils make up $6.7 \%$ and $3.1 \%$ of controlled primary and non-selective secondary schools respectively whilst non-Catholic pupils represent $3.4 \%$ and $2.9 \%$ respectively in the mirror image Catholic maintained schools. Controlled and non-Catholic voluntary grammar schools have $8.5 \%$ and $12.2 \%$ designated Catholic enrolments respectively but Catholic grammar schools are almost exclusively Catholic (97.3\%). The 62 integrated schools together host $7.0 \%$ $(21,398)$ of all primary and secondary-level pupils, of whom $36.6 \%$ are Catholic.

Integrated education has been a feature of the education landscape since the opening of the first school, Lagan College, in 1981. For some time the prospects for a radical alternative to the bipartite system looked bright, bolstered by the 1989 Education Reform Order, which placed a statutory onus on the Department of Education to 'encourage and support integrated education' (ERO, 1989, Art 64 (1)). However, the sector has faced many difficulties including open opposition from the Catholic Church, which for many years refused to minister to the spiritual needs of Catholic children in integrated schools, and antagonism from some sections of communities when the creation of a new integrated school threatened the sustainability of existing local schools. The granting of controlled integrated status to schools with little or no prospect of meeting integrated criteria (which require $10 \%$ enrolment from the minority community in year 1 and the potential to reach $30 \%$ in the longer term) has for some schools been a safety net against closure in the face of falling rolls. It is an open question as to whether this type of faux-integration has undermined the development of integrated education. Despite consistently strong public endorsement (e.g. 68\% reported in the Belfast Telegraph, 2013) and the high profile support of such dignitaries as President Obama (during his January 2013 visit) this form of shared education has grown very slowly to its present $7 \%$ proportion of the national enrolment (for a thorough overview of integrated education see Montgomery, Fraser, McGlynn, Smith and Gallagher, 2003; Hansson, O'Connor-Bones and McCord, 2013).

Hughes (2011) argues that 'integrated schools for all children are not a realistic option. Nor is it conceivable that education will ever become secularized' (2011, p. 847). She makes three observations: that the separateness of schools and their pupils is based on their strong interconnectedness with their local community (borne out empirically by Graham and Nash, 2006, and Roulston and Young, 2013); that teachers are reluctant to challenge strong in-group identities; and that school status is identity. With this latter observation she argues that a Catholic school has a clear Catholic identity whilst however much some might promote a 'non-denominational' ethos for controlled schools they are much more accurately identified as Protestant. The non-denominational approach 'could be construed as subordinating Protestant identity distinctiveness, thereby denying Protestant pupils a basis on which to engage with their Catholic peers' (Hughes, 2011, p. 846). Her 
argument continues by asserting that sustained collaboration between schools, i.e. shared education, is one pathway to better inter-group relations but is contingent on controlled schools 'taking ownership of their distinctly Protestant identity' (p.847).

As a concept, 'shared education' was first formally enshrined in government-speak during the term of office of the direct rule Secretary of State, Paul Murphy. Entitled A Shared Future: Policy and Strategic Framework for Good Relations in Northern Ireland (OFMDFM, 2005), the framework envisaged a shared society at all levels and in all spheres including the community, the workplace and education. Shared education was one of the main themes of the seminal Burns Report (2001, see below) and since 2007 it has also been the subject of a major continuing project, the Sharing Education Programme (Gallagher, Stewart, Walker, Baker and Lockhart, 2010) sponsored by Atlantic Philanthropies and the International Fund for Ireland. The concept is complex and involves schools of various types working together to promote efficient use of resources, equality of opportunity and identity, and respect for diversity and community cohesion (Gallagher's paper, in this issue, addresses shared education developments in detail). The most recent development, a Shared Education Bill, is currently being drafted by the Minister of Education for approval in early 2016 (DENI, 2015b) based on an all-encompassing vision for: 'Vibrant, self-improving Shared Education partnerships delivering educational benefits to learners, encouraging the efficient and effective use of resources, and promoting equality of opportunity, good relations, equality of identity, respect for diversity and community cohesion' (p.4).

\section{Implications of Segregated Schooling}

Segregated schooling in Northern Ireland is considered by some sections of the public to be a good thing for protecting culture, promoting faith-based values and, close to many people's concerns, providing safety for children in what at times can be a volatile environment. None of these considerations can be seriously faulted but many might agree with the Democratic Unionist First Minister, Peter Robinson, that the Northern Ireland education system is a 'benign form of apartheid' and that 'we cannot hope to move beyond our present community divisions while our young people are educated separately' (Belfast Telegraph, 2010). However, his solution - that the government should stop funding Catholic schools - was unlikely to find favour with many people beyond his party faithful.

The duplication of schools, or indeed triplication in instances where an integrated school competes with local controlled and Catholic schools, underpins an economic argument against such nationalscale segregation, and the figures are startling. In 2006, the Bain Review, which focused on the wasteful inappropriateness of the system, estimated that 53,000 places ( $15 \%$ of the total capacity) in existing schools were unfilled. The report strongly endorsed the need for the school estate to be rationalized and for schools to share resources. The Northern Ireland Audit Office (NIAO) now estimates that there are 71,000 surplus places in schools (NIAO, 2015). This represents approximately $20 \%$ of capacity and crosses both sectors: $45 \%$ in non-denominational schools and $49 \%$ in Catholic schools. The NIAO (2015) suggests that $70 \%$ of the surplus places are in primary schools and that 271 of these have enrolments of less than 100 pupils.

Table 1 shows that at the time of the Agreement in 1998, there were 916 primary schools (DENI, 2012) and every minister of education since then, faced with dwindling budgets, has struggled with the problem of school duplication and small schools. The closure of schools for budgetary or operational reasons in any part of the UK, and in many developed countries, often faces considerable community opposition but in Northern Ireland it is invariably more contentious. As parents face the choice of enrolling their children in a school that mainly serves the 'other' community or sending them on much longer journeys to an alternative school serving their own community, it is not unknown for unsavoury elements to mount a more menacing opposition to closure proposals. 
Although the number of primary schools has fallen to 822 (DENI, 2015a), a reduction of 94 in 17 years, the NIAO note that the 2014/15 cost to sustain small schools (some with as few as 19 pupils) remains very high at $£ 36$ million in additional grants; and they pull no punches in pressing the Department of Education to do more to plan and manage the surpluses and school sustainability.

Another implication of segregated education is the need for teachers to be trained in the ethos appropriate to the schools in which they teach, i.e. segregated teacher education. Most tertiary education in Northern Ireland, comprising the large further education colleges and the two universities, is integrated; i.e. students of all cultural backgrounds routinely study together. The two teacher education colleges, however, largely reflect the primary school communities they serve: the one non-denominational (Stranmillis), the other Catholic (St Mary's).

Over time, this segregation of teacher education has been challenged politically and academically, especially as the two universities have been training teachers successfully in an integrated fashion for many years. In 1982, for example, the Chilver Committee's review of Northern Ireland higher education precipitated a furore by proposing a merger of the colleges (Chilver, 1982). The Catholic Church's reaction involved rallying opposition in its schools and parishes and ultimately the proposals were shelved. It was not until the early 2000s, on foot of the Agreement, that a new impetus began to form around the pursuit of integrated teacher education. Under the devolved government structure, the Department for Employment and Learning (DEL) had responsibility for funding higher education, including teacher education, and in consort with the Department of Education (with responsibility for schools) it renewed efforts to unify teacher education. Consultations and workshops involving all stakeholders teased out different models of integration, federation and collaboration. There were mixed reactions from the Protestant churches and Stranmillis University College but resolute intransigence from the Catholic authorities and St Mary's University College. Interpreting the various proposals as attempts to undermine Catholic education, all arguments relating to such benefits as improved social cohesion, community integration and financial efficiencies were met with at best silence and at worst vociferous rejection. Chastened by the aggressive tone of the various negotiations, DEL repositioned itself and in 2013 commissioned an international team to review the teacher education arrangements.

The ensuing Report of the International Review Panel on the Structure of Initial Teacher Education in Northern Ireland (DEL, 2014) was particularly hard-hitting, with the panel asserting that the teacher education system has a number of serious weaknesses and unsustainable characteristics relating to:

- A small and deeply fragmented system with only 1400 students between the institutions;

- Inappropriate policy making that aims to keep the university colleges financially viable rather than addressing the skill base needed for an advanced economy;

- The quality of provision in relation to international trends;

- Unemployment among new graduating teachers of almost 82\%;

- Significantly higher costs compared to UK norms for teacher education in the two small and largely mono-technic institutions: 38\% higher costs in Stranmillis and 31\% in St Mary's;

- Inequitable treatment of Stranmillis students who must complete a Glasgow University programme if they wish to teach in Catholic primary or nursery schools;

- The anomalous system of accepting applicants who have not registered with the UK Universities and Colleges Admissions Service, UCAS.

It is clear that teacher education in Northern Ireland has a considerable distance to travel if it is to present as a modern system fit for the needs of today's society. 


\section{Segregation by Academic Selection}

The second key focus of this paper is Northern Ireland's almost unique system of state-endorsed academic segregation in secondary education. Children leaving primary education may transfer directly to non-selective secondary schools or they may compete for a place in a grammar school, with entry dependent on their performance in academic transfer tests. However, many of the children who wish to transfer to a grammar school are turned away because of their grades and may face the stigma of having 'failed' the transfer tests well into their adult life. The reforming mood inspired by the Agreement initiated a raft of studies, policy reviews and attempts at changing this system but also faced the same conservative and partisan reactions as attempts at addressing religiously segregated education had faced for decades before (and since). The irony, however, is that the threat to academic selection found common ground across the segregated systems with Catholic and Protestant grammar schools united in defending middle-class interests under their umbrella group, the Governing Bodies Association (GBA). These class-based motivations for academic selection are tellingly underlined by its socially segregating effect on Northern Ireland's children. In $2012 / 13$, for example, 56 of the 68 grammar schools had fewer than $10 \%$ of pupils who were entitled to free school meals, and of these at least 10 had less than 4\%. (Nolan, 2014).

The selective system had its origins in the Education Act (Northern Ireland) 1947 as a follow-on to the UK Conservative government's 1944 introduction of free entry to all English and Welsh schools. The Education Act (1944) enabled admission to grammar schools on the basis of performance in academic ' $11+$ ' tests, so-called as they were administered in the child's last year at primary school, normally at 11 years of age. According to Walker (2010), the GBA had opposed the Order because it wished to continue to admit students on a fee-paying basis (the main income stream for grammar schools at that time) regardless of their performance on any academic selection test. The privileging of fee-payers was ultimately conceded by the Northern Ireland government, though subject to capped numbers, and the Order passed through parliament. Inequalities remained, however, and according to Walker pupils attending non-grammar schools were not permitted to take public examinations right up to the 1970s (Walker, 2010, p 12).

Whilst controversy around religion-based segregation has flared and smouldered over the decades, academic selection has been a constant feature of educational concern and debate. Successive government reports from the 1960s onward had expressed concerns about it. In 1964, for example, the Northern Ireland Minister of Education noted that the most serious educational problem of the time was the 11+ examination for grammar school entry; and posed the question as to 'whether the existing system of secondary education should be continued or replaced by a new system based on some form of comprehensive school' (HMSO, 1964, p.8). In 1971, the Advisory Council for Education in Northern Ireland specifically examined the selection procedure and in an almost hidden caveat to their conclusions they felt the Council 'would be in danger of conveying a false impression ... if it did not express grave disquiet regarding the principle of selection' (ACENI, 1971, p.27). In 1973, the Council returned more resolutely to the issue when they recommended that the Minister of Education should declare the intention to eliminate selection at $11+$ as soon as possible (ACENI, 1973).

Public attention waxed and waned during the 1980s and early 1990s until in 1996 the Department of Education released a report, Free School Meals and Low Achievement, which powerfully illustrated the inequalities in the system (DENI, 1996). Children who were entitled to free school meals were much less likely to stay at school after the compulsory age (16 years) or to proceed to further or higher education. The focus fell on grammar schools again and the advantages/disadvantages that academic segregation creates for pupils. Time after time over the period since the Agreement, significant bodies have criticised the Northern Ireland education system for the inequalities in opportunities and outcomes of the type and extent that were illustrated in the DENI Free School 
Meals bulletin above. In the review of 1992-99, for example, the Chief Inspector of Schools observed that many young people leave compulsory education with low standards of literacy and numeracy (ETI, 2001).

Right up to the present day, the Education and Training Inspectorate has unequivocally identified the weaknesses of the system in relation to disadvantaged pupils. In the 2010-12 Chief Inspector's Report (ETI, 2012) it was expressed as the need to improve outcomes in English and mathematics for those entitled to free school meals ('only $32 \%$ of all school leavers entitled to free school meals achieved five GCSE $A^{*}-C$ grades including English and mathematics' p.6). In the 2012-14 report (ETI, 2014) a slight improvement to $34 \%$ is registered (p3) with the rider that 'The outcomes for our most vulnerable learners are not good enough' (p.7). The report highlights the diminishing performance gap between grammar and non-selective schools, with only $30 \%$ difference in the proportions of all pupils achieving at least 5 x GCSEs at A*-C grades - compared to the $53 \%$ gap in 2005/6. Perhaps more tellingly the report registers the need to 'reduce the variability in the life chances of children and young people' (p.3).

One of the most repeated arguments from proponents wishing to maintain academic selection is that Northern Ireland's education system is the envy of Britain if not the world. Pupils taking A-levels often accumulate more high grades than their counterparts in England and Wales, and the observation is often made that a system designed to deliver such high quality outcomes would be very expensive in England (via private fee-paying school places) but in Northern Ireland it is free, i.e. grammar schools focus on attaining high grades and attendance at them is at a cost to the taxpayer not the pupil or parents. Non-grammar schools are also fully funded by the taxpayer but their outcomes are lower despite the attenuating difference mentioned above. The factors contributing to the difference can be at least partly ascribed to pupil-based characteristics such as commitment to education, family background, level of aspiration and disadvantage through poverty. Poverty is a major dimension of disadvantage in Northern Ireland with estimates ranging from 95,000 (Nolan, 2014) to 149,000 Northern Ireland children (Hillyard, Kelly, McLaughlin, Patsios and Tomlinson, 2003) living in designated 'poor' households. Indeed, the socio-economic differences between the two parts of the state-funded system are often commented upon by international observers, the most recent being the Organization for Economic Cooperation and Development (OECD): 'The concentration of less socio-economically advantaged students in some schools is a recognized challenge in Northern Ireland' (Shewbridge, Hulshof, Nusche, and Staehr, 2014, p.28).

The performance of grammar schools, in light of the decreasing difference above, is worthy of some scrutiny. With $44 \%$ of all secondary-level admissions, grammar schools cannot justify the segregation of children on the basis of an arbitrary potential to benefit from a grammar school education. The question is begged: in what sense would the other $56 \%$ not benefit from this? Additionally, their much vaunted performance is not as universally good as the GBA might propose. In a recent analysis of their performance, (Belfast Telegraph, 2015) ten of the 68 grammar schools had pupils with three good A-level passes at proportions less than the $65 \%$ average for the whole secondary sector. This compares unfavourably to five non-selective schools with 64+\% success (Nolan, 2014, p.96).

The two main unionist parties and the GBA have consistently blocked any attempt to abolish academic selection despite widespread concern about its impact on the sizeable group of pupils who each year fail to get a place in a grammar school. In 2006, the Westminster Public Accounts Committee (Belfast Telegraph, 2006) expressed its concern about outcomes for some pupils from the non-selective secondary sector and especially the outcomes for disadvantaged Protestant children in controlled schools. They described the statistic for pupils obtaining $A^{*}-C$ grades in GCSE mathematics as 'appalling' (4.4\%) with better but still very poor figures for GCSE English (17\%). The proportion of Northern Ireland Protestant boys, who are entitled to free school meals, achieving $5 x$ GCSEs at $A^{*}-C$ grades (inc. maths and English) is $19.7 \%$, the third lowest performing grouping in the UK and a long 
way below the $62 \%$ average for all Northern Ireland pupils (Nolan, 2014, p.98). Nevertheless the unionist parties and the GBA continue to defend the system, prompting Kelly $(2011$, p.94) to observe that the unionists appear to treat Protestant working class children as mere 'education fodder in this middle-class system' when it comes to educational achievement.

The debate about inequalities, which some consider to be caused or at least perpetuated by the selective system, took on renewed vigour when a Labour government was returned in the UK in 1997. However, the direct rule minister did not seek to remove selection and called instead for more research. In the year of the Agreement, the Department of Education duly commissioned a 27member team of academics from four institutions to examine a wide variety of effects of the selective system. The project reported in September 2000 (Gallagher and Smith, 2000) and was a tour de force of objective analysis of the effects of selection on Northern Ireland society. In parallel research into the $11+$ transfer tests themselves, Gardner and Cowan $(2000,2005)$ used three versions of the tests with 52 primary schools and over 2,000 pupils to demonstrate unequivocally that the tests were technically unreliable and could only be trusted to differentiate the cohort into the top $12 \%$ and lowest $18 \%$ performing pupils. To add salt to the wounds, the data showed that only 18 marks (out of 150) separated the top A grading band from the lowest D band - and in the year in question this would have scaled up to affect over 12,000 children. The conceit of discriminating fairly between so many children over an 18 mark range was comprehensively exposed.

\section{Academic Selection since the Good Friday Agreement}

The selection debate began to gather momentum almost as soon as the devolved assembly was inaugurated in 2000. The first Minister of Education, Martin McGuinness, came from Sinn Fein, a party which was on record as being opposed to selection. Following on the Gallagher and Smith reports, he commissioned a major review of Northern Ireland education, the Burns Review.

The Burns Report (Burns 2001), officially published as the Report of the Review Body on Post-Primary Education, caught the reformist mood of the educational community but not the wider public and their political representatives. Strong forces railed against the proposals to abolish academic criteria for transfer to secondary education (the report proposed criteria ranging from having siblings at a school to distance from the child's home) and to create 20 'collegiate' networks of secondary-level schools, with each collegiate comprising Catholic, controlled, integrated and Irish-medium schools. The grammar school bloc was particularly outraged that their academic ethos could be lost and unionist politicians baulked at the idea of a Sinn Fein minister telling them what to do with Northern Ireland's schools.

The Burns Report galvanized the reformers and provoked the naysayers with its innovative and farreaching proposals. However, during 2002 the strains of shared government were precipitating a constitutional crisis, which quickly led to the suspension of the Northern Ireland Assembly and a new period of direct rule that lasted until 2007. The Sinn Fein Minister of Education's parting shot, dramatically close to midnight on the eve of suspension (13 October 2002), was to abolish the transfer tests with effect from 2004. His action initiated several years of turmoil born of uncertainty fuelled by a political vacuum. What would replace the transfer tests? What would happen to grammar schools?

The 'objective' actors in this escalating situation were the direct rule ministers of education. Although at times they must have felt they were trying to bring order to a room full of precocious and squabbling children, they tried earnestly to move matters forward. The first in a series of four, Jane Kennedy, commissioned the Costello Working Group in early 2003 to review the Burns proposals. The Costello Report (2003) broadly endorsed the direction of travel of Burns but proposed looser confederations of schools, instead of fixed collegiate networks, to share resources 
and engage in cross-community activities. The group also endorsed the abolition of academic selection for entry to secondary level schools. In accepting all of the Costello recommendations, Kennedy (BBC, 2004) confirmed that the last tests would now be in 2008 (four years after the McGuinness target of 2004). In 2005, the then secretary of state, Angela Smith, drew up proposals for a new Education (Northern Ireland) Order, which inter alia would confirm in statute that selection on academic grounds was abolished.

In an attempt to appease opposition from unionist politicians and the grammar schools, Smith's proposals (DENI, 2005) signalled categorically that the Order would not abolish grammar schools and would not impose a system of all-ability comprehensive schools. Nevertheless, the analysis of the consultation responses (DENI 2006) illustrates how a campaign-style opposition was marshalled. Of 10,118 written responses, 8,900 were on a common form distributed by a group, Concerned Parents for Education, strongly opposed to the abolition of academic selection. In contrast, a wide range of bodies supported the proposal to prohibit the use of academic selection as an admissions criterion. These included three of the five education and library boards (the authorities for controlled, nondenominational schools), the Catholic Maintained Schools Commission, the Catholic Trustees group, the Northern Ireland Council for Integrated Education, Sinn Fein, the Social Democratic and Labour Party and the main teacher unions. More qualified support, tempered for example by concerns about operationalizing the criteria, was expressed by the Transferor Representatives Council, the General Teaching Council and others. Ultimately, the range and combination of the more thoughtful responses, though much smaller in number, was considered to be more valid than the monopolizing potential of the multiple response campaign groups.

However, bigger prizes were at stake. Prime Minister Tony Blair had designs on getting agreement for a return to a devolved government and one of the key elements prompting the DUP's very public intransigence in negotiations with him was the perceived threat to grammar schools arising from the abolition of academic selection. He subsequently had the draft order amended, in June 2006, to make the abolition of academic selection subject to the decision of Northern Ireland Assembly if the parties agreed to a new model of devolved government by November $23^{\text {rd }}$ of that year (DENI, 2006). The decision horrified those in favour of desegregating the two tier non-selective and grammar school system and delighted those who wished the status quo to be maintained. In due course, however, the intervention helped Blair to achieve a last gasp deal at the negotiations in St Andrews, Scotland. If Blair's tactics might be considered cynical, in seeking agreement at any cost for another breakthrough feather in his diplomacy cap, Sinn Fein's agreement to a de facto veto for the unionist bloc on matters of academic selection was an extraordinary volte face, sacrificing their avowed social justice principles for the prize of shared power. Eventually, a devolved assembly was restored and as expected the unionist bloc did exercise their right not to allow the abolition of academic selection. During a long drawn out battle in the Assembly chamber and the media, in which the future life-chances of thousands of children played second fiddle to party politics and middle-class pressure, the unionists and GBA rejected a series of proposed compromises from the new Sinn Fein Minister of Education, Catriona Ruane. Finally all she could do was ensure that state involvement in academic selection would end whilst permitting grammar schools to organize their own, unregulated entrance tests. This they duly did. However, having won the battle to save academic selection as a unified opposition, they quickly retreated to their tribal comfort zones and opted to replace the fundamentally flawed, state system with their own independent systems. Northern Ireland children now have the unenviable choice of separate 'Protestant' and 'Catholic' test systems for grammar schools; test systems with serious ethical questions to answer (see Elwood, 2013), of uncertain technical reliability and validity, no comparability of outcomes between them and no significant government oversight. 


\section{Concluding Remarks}

The Good Friday Agreement prompted considerable optimism for a brighter future for Northern Ireland and in many respects it has delivered, albeit with a few false-starts. In education, however, the wider Northern Ireland society remains unreconciled on a system segregated by religion and by academic selection. Much innovative work has been carried out on the former, most recently and intensely in exploring shared education; though without any sizable impact on the segregated system as yet. However, attempts at resolution of the latter have foundered on deeply entrenched views that Northern Ireland's children should be systematically separated at 11 years of age into grammar and non-grammar schools. Grammar schools are perceived as offering a direct line to university and employment; and this avenue to opportunity is jealously guarded by the middleclasses in both communities who benefit most from it.

Successful change in these crucial matters might reasonably have been guaranteed by common cause between the two communities. Alas, this has been a rare commodity, often usurped or eclipsed by horse-trading between the main political parties. Nothing exemplifies the continuing unedifying lack of leadership and integrity in the country's governance better than the seven years and $\mathrm{f17}$ million expended on attempts to create a unitary Education and Skills Authority (see BBC, 2014). Designed to bring under one management system the employing authorities of all schools (education and library boards, the Staff Commission, Catholic Council for Maintained Schools and the Youth Council) it had the endorsement of Sinn Fein but predictably, therefore, the opposition of the DUP. Ultimately it was brought down by a combination of unionist politicians concerned about the management of controlled (Protestant) schools and the GBA, who feared the erosion of grammar school autonomy. A watered down version, the Education Authority, is now in operation.

In the context of academic selection at 11 , the various actors have retreated to their traditional positions. The Catholic Church continues to swither between not wishing to promote the immorality of state-sponsored disadvantage and the cynical protection of some of its top grammar schools; the GBA maintains their 'not an inch' stance on what it sees as the cream of UK education under attack, the DUP remain callously indifferent to the effects of a system that condemns children in their heartland working class constituencies to poorer outcomes than their Catholic peers, and Sinn Fein continue to make their social justice agenda expedient to their power hungry pragmatism.

In the years since the Good Friday Agreement, the various protagonists have repeatedly taken up counter positions on these important matters, ostentatiously scoring points off each other in an education sub-plot of the Kabuki-esque theatre that is Northern Ireland politics. The centuries old scripts rarely change as entrenched views provoke predictable behaviours, replete with their customary posturing and bluster and the colourful but often menacing mix of symbolic masks, emblems, costumes and regalia. Unlike Kabuki, however, there is little of entertainment value as cynical politicians and some education leaders pursue their unmoderated sectional interests in a ritual of tit-for-tat obstruction and manipulation. The ultimate casualties of this relentless 'danse macabre' are not the main participants; they are the children of Northern Ireland and their lifechances.

\section{References}

ACENI (1971) The existing selection procedure for secondary education in Northern Ireland, Advisory Council on Education for Northern Ireland Cmd 551. Belfast: Her Majesty's Stationery Office

ACENI (1973) Reorganisation of secondary education in Northern Ireland, Advisory Council on Education for Northern Ireland Cmd 574. Belfast: Her Majesty's Stationery Office 
Bain, G. (2006) Schools for the future: funding, strategy and sharing. Report of the Independent Strategic Review of Education. Retrieved from http://dera.ioe.ac.uk/9777/1/review of education.pdf

BBC (2004) 11+ to be abolished. Retrieved from http://news.bbc.co.uk/1/hi/northern ireland/3429541.stm

BBC (2014) ESA: John O'Dowd scraps Education and Skills Authority plan. Retrieved from http://www.bbc.co.uk/news/uk-northern-ireland-27627932

Belfast Telegraph (2006) How the school system is failing Protestant children in deprived areas. Retrieved from http://www.belfasttelegraph.co.uk/news/how-the-school-system-is-failingprotestant-kids-in-deprived-areas-28116864.html

Belfast Telegraph (2010) Peter Robinson calls for the end to school segregation. Retrieved from http://www.belfasttelegraph.co.uk/news/education/peter-robinson-calls-for-end-to-schoolsegregation-28565048.html

Belfast Telegraph (2013) Public mood in Northern Ireland is for an end to segregation in schools. Retrieved from http://www.belfasttelegraph.co.uk/opinion/debateni/public-mood-innorthern-ireland-is-for-an-end-to-segregation-in-schools-29372424.html

Belfast Telegraph (2015) Northern Ireland schools league tables - Catholic grammars lead the way at GCSE but top schools failing at A-level. Retrieved from: http://www.belfasttelegraph.co.uk/news/education/exclusive-northern-ireland-schoolsleague-tables-catholic-grammars-lead-the-way-at-gcse-but-top-schools-failing-at-alevel31089536.html

Brewer, J. D. with Higgins, G. I. (1998) Northern Ireland: 1921-1998. Retrieved from http://cain.ulst.ac.uk/issues/sectarian/brewer.htm

Burns, G. (2001) Report of the Review Body on Post-Primary Education. Retrieved from https://www.deni.gov.uk/publications/report-review-body-post-primary-education-burnsreport

Chilver, H. (1982). The Future of Higher Education in Northern Ireland. Report of the Higher Education Review Group for Northern Ireland. Belfast: HMSO

Costello, S. (2004) Report of the Post-Primary Review Working Group. Retrieved from https://www.deni.gov.uk/publications/costello-report-full

Craig, J. (1934) The Stormont Papers 21 November 1934, 35, 73. Retrieved from http://stormontpapers.ahds.ac.uk/stormontpapers/pageview.html?volumeno=17\&pageno=73

DEL (2014) Final Report of the International Review Panel on the Structure of Initial Teacher Education in Northern Ireland https://www.delni.gov.uk/sites/default/files/publications/del/Structure\%20of\%20Initial\%20Te acher\%20Education\%20in\%20Northern\%20Ireland\%20Final\%20Report.pdf

DENI (1996) Free school meals and low achievement. Statistical bulletin SB2. Bangor: Department of Education for Northern Ireland

DENI (2005) New post-primary arrangements: a statement by Angela Smith, MP, Minister for Education. Bangor: Department of Education for Northern Ireland

DENI (2006) Proposal for a draft Education (Northern Ireland) Order: Summary of the responses to the consultation on the proposal for a draft education order. Bangor: Department of Education for Northern Ireland

DENI (2012) Compendium of Northern Ireland education statistics, 1998/99 to 2010/11. Bangor: Department of Education for Northern Ireland. Retrieved from https://www.deni.gov.uk/sites/default/files/publications/de/compendium-9899-to-1011.pdf

DENI (2015a) Enrolments at schools and in funded pre-school education in Northern Ireland, 2014/15. Bangor: Department of Education for Northern Ireland. Retrieved from https://www.deni.gov.uk/sites/default/files/publications/de/Statistical\%20bulletin\%20\%20February\%2015\%20FINAL\%20\%2824.06.15\%29.pdf 
DENI (2015b) Sharing works: a policy for shared education. Retrieved from: Education Act (1944). Bangor: Department of Education for Northern Ireland Retrieved from https://www.deni.gov.uk/sites/default/files/publications/de/shared-education-policy.pdf

Education Act (Northern Ireland) (1947). Retrieved from http://www.educationengland.org.uk/documents/acts/1947-education-act-ni.html

Elwood, J. (2013) Educational assessment policy and practice: a matter of ethics. Assessment in Education: Principles, Policy and Practice, 20 (2) 205-220

ETI (2001) Chief inspector's review, 1992-99. Bangor: Education and Training Inspectorate. Retrieved from http://www.etini.gov.uk/report_detail.asp?id=239

ETI (2012) Chief inspector's report, 2010-12. Bangor: Education and Training Inspectorate. Retrieved from http://www.etini.gov.uk/index/inspection-reports/the-chief-inspectors-report/ci-report2012.pdf

ETI (2014) Chief inspector's report, 2012-14. Bangor: Education and Training Inspectorate. Retrieved from http://www.etini.gov.uk/index/inspection-reports/the-chief-inspectors-report/ci-report2012-2014.pdf

Gallagher, A. M. and Smith, A. (2000) The effects of the selective system of secondary education in Northern Ireland, Main Report and Research Papers Volumes 1 and 2. Retrieved from http://www.education.gg/CHttpHandler.ashx?id=97491\&p=0

Gallagher, T., Stewart, A., Walker, R., Baker, M. and Lockhart, J. (2010) Sharing education through schools working together. Shared Space 10, 65-74

Gardner, J. and Cowan, P. (2000) Testing the test: a study of the reliability and validity of the Northern Ireland transfer procedure test in enabling the selection of pupils for grammar school places. Retrieved from http://core.ac.uk/download/pdf/309206.pdf

Gardner, J. and Cowan, P. (2005) The fallibility of high stakes '11-plus' testing in Northern Ireland. Assessment in Education: Principles, Policy and Practice 12 (2) 145-165

Graham, B. and Nash, C. (2006) A shared future: territoriality, pluralism and public policy in Northern Ireland. Political Geography 25 (3) 253-278

Guardian (2012) The religious divide in Northern Ireland's schools. Retrieved from http://www.theguardian.com/news/datablog/2012/nov/24/religious-divide-northern-ireland$\underline{\text { schools }}$

Hansson, U., O'Connor-Bones, U. and McCord, J. (2013) Integrated education: a review of policy and research evidence 1999-2012. Retrieved from

http://www.unescocentre.ulster.ac.uk/pdfs/pdfs unesco centre publications/2013 0221 in $\mathrm{t}$ ed-a review of the evidence 1999 to 2012-review of policy and research evidencefull report jan 2013.pdf

Hillyard, P., Kelly, G., McLaughlin, E., Patsios, D. and Tomlinson, M. (2003) Bare necessities: poverty and social exclusion in Northern Ireland. Key findings. Retrieved from http://www.ofmdfmni.gov.uk/bare-necessities.pdf

Hughes, J. (2011) Are separate schools divisive? A case study from Northern Ireland. British Educational Research Journal, 37 (5) 829-950

HMSO (1964) Educational development in Northern Ireland 1964. Cmd 470 Belfast: Her Majesty's Stationery Office

Kelly, A. (2011) Educational effectiveness and school improvement in Northern Ireland: opportunities, challenges and ironies. In Chapman, C. P., Armstrong, P., Harris, A., Muijs, D., Reynolds, D. and Sammons, P. (eds.) School Effectiveness and Improvement Research, Policy and Practice: Challenging the Orthodoxy? Abingdon, GB, Routledge, pp 81-96.

Londonderry, Lord. (1923) The Stormont Papers, 14 March 1923, 3, 125. Retrieved from http://stormontpapers.ahds.ac.uk/stormontpapers/pageview.html?volumeno=3\&pageno=125

McGuffin, S. (1923) The Stormont Papers, 23 February 1923, 3, 139. Retrieved from http://stormontpapers.ahds.ac.uk/stormontpapers/pageview.html?volumeno=3\&pageno=139 
Montgomery, A., Fraser, G., McGlynn, C., Smith, A. and Gallagher, T. (2003) Integrated education in Northern Ireland: integration in practice. Retrieved from:

http://www.unescocentre.ulster.ac.uk/pdfs/pdfs alan/2003 Integrated Education in NI Inte gration in Practice.pdf

NIAO (2015) Department of Education: Sustainability of Schools. Report by the Comptroller and Auditor General. Belfast: Northern Ireland Audit Office. Retrieved from http://www.niauditoffice.gov.uk/135119 niao sustnblty in schls for web v6.pdf

NIO (1998) The Belfast Agreement. Northern Ireland Office. Retrieved from https://www.gov.uk/government/publications/the-belfast-agreement

Nolan, P. (2014) Northern Ireland Peace Monitoring Report No. 3. Retrieved from http://www.community-relations.org.uk/wp-content/uploads/2013/11/Peace-MonitoringReport-2014.pdf

Roulston, S. and Young, O. (2013) GPS tracking of some Northern Ireland students - patterns of shared and separated space: divided we stand? International Research in Geographical and Environmental Education 22 (3) 241-258

Shewbridge, C., Hulshof, M., Nusche, D. and Staehr, L. S. (2014) Northern Ireland, United Kingdom. OECD Reviews of Evaluation and Assessment in Education. Retrieved from: http://www.oecd.org/edu/school/Reviews\%20of\%20Evaluation\%20and\%20Assessment\%20in \%20Education\%20Northern\%20Ireland.pdf

Stanley, E. G. (1831) Letter. In Reports of the Commissioners of National Education in Ireland for the Years 1834, 1835 and 1836. Retrieved from http://tinyurl.com/otrjq2q

Walker, A. (2010) Selection challenged: the case against selection for 11+. Newtownards: Colourpoint 


\begin{tabular}{|c|c|c|c|c|c|c|c|c|}
\hline \multirow[t]{2}{*}{ School Types } & \multirow{2}{*}{$\begin{array}{c}98 / 99 \\
\mathrm{~N}\end{array}$} & \multicolumn{2}{|c|}{$14 / 15$} & \multirow{2}{*}{$\begin{array}{c}\text { Total } \\
\text { Enrolment } \\
14 / 15 \\
\mathrm{~N}\end{array}$} & \multicolumn{2}{|c|}{$\begin{array}{c}\text { Enrolments Recorded as } \\
\text { Protestant* } \\
14 / 15\end{array}$} & \multicolumn{2}{|c|}{$\begin{array}{l}\text { Enrolments Recorded as } \\
\text { Catholic } \\
14 / 15\end{array}$} \\
\hline & & $\mathbf{N}$ & $\%$ & & $\mathbf{N}$ & $\%$ & $\mathbf{N}$ & $\%$ \\
\hline \multicolumn{9}{|l|}{ Primary } \\
\hline Controlled & & 370 & 45.0 & 75688 & 51708 & 68.3 & 5051 & 6.7 \\
\hline Catholic Maintained & & 381 & 46.4 & 75771 & 579 & 0.8 & 73197 & 96.6 \\
\hline Other Maintained & & 29 & 3.5 & 2872 & 276 & 9.6 & 2369 & 82.5 \\
\hline Controlled Integrated & & 19 & 2.3 & 3733 & 1518 & 40.7 & 1118 & 29.9 \\
\hline Grant Maintained Integrated & & 23 & 2.8 & 5671 & 1800 & 31.7 & 2443 & 43.1 \\
\hline $\begin{array}{ll} & \text { Totals } \\
\end{array}$ & 916 & 822 & 100 & 163735 & 55881 & 34.1 & 84178 & 51.4 \\
\hline \multicolumn{9}{|l|}{ Secondary Non-Grammar } \\
\hline Controlled & & 51 & 36.4 & 27918 & 22714 & 81.4 & 860 & 3.1 \\
\hline Catholic Maintained & & 68 & 48.6 & 39347 & 467 & 1.2 & 38189 & 97.1 \\
\hline Other Maintained & & 1 & 0.7 & 581 & 0.0 & 0.0 & 542 & 93.3 \\
\hline Controlled Integrated & & 5 & 3.6 & 2502 & 1634 & 65.3 & 402 & 16.1 \\
\hline Grant Maintained Integrated & & 15 & 10.7 & 9492 & 4026 & 42.4 & 3867 & 40.7 \\
\hline $\begin{array}{ll}\text { Totals } \\
\end{array}$ & 165 & 140 & 100 & 79840 & 28841 & 36.1 & 43860 & 54.9 \\
\hline \multicolumn{9}{|l|}{ Secondary Grammar } \\
\hline Controlled & & 18 & 26.5 & 15787 & 11959 & 75.8 & 1335 & 8.5 \\
\hline Voluntary (Catholic) & & 29 & 42.6 & 27391 & 260 & 0.9 & 26658 & 97.3 \\
\hline Voluntary (Other) & & 21 & 30.9 & 19535 & 12701 & 65.0 & 2381 & 12.2 \\
\hline Totals & 72 & 68 & 100 & 62713 & 24920 & 39.7 & 30374 & 48.4 \\
\hline Grand Totals & 1153 & 1030 & 100 & 306288 & 109642 & 35.8 & 158412 & 51.7 \\
\hline
\end{tabular}

